\title{
Research on the Strategic Development of Gwadar Port Logistics under the Background of the Belt and Road and China-Pakistan Economic Corridor
}

\author{
Aimin Deng, Jiaqi Wang
}

\begin{abstract}
In the context of the successful launch of the Belt and Road and China-Pakistan Economic Corridor projects, this paper firstly reviews and draws lessons from the domestic and foreign trends of the research on port evolution, developing force and development strategy; combining policies, port evolution laws and Pakistan's social economy to determine Gwadar Port development goal and development path. On this basis, Gwadar Port is provided with six development strategies, namely the port-industry-city-region integration, alliance strategy, differentiation strategy, strategy of sustainable development, opening-up strategy and talent strategy, and specific measures are given according to the objectives of the three stages to ensure the smooth implementation of the six strategies. This paper has certain reference significance for studying the development strategies, targets and measures of similar port logistics.
\end{abstract}

Index Terms-Gwadar Port, The Belt and Road, China-Pakistan Economic Corridor, logistics strategy, strategic development, strategic research.

\section{INTRODUCTION}

In March 2015, the National Development and Reform Commission, the Ministry of Foreign Affairs and Ministry of Commerce jointly issued Vision and Actions on Jointly Building Silk Road Economic Belt and 21st-Century Maritime Silk Road. In April of the same year, the China-Pakistan Economic Corridor (CPEC) project was officially launched, focusing on Gwadar Port, energy, transportation infrastructure and industrial cooperation, forming a "1+4" economic cooperation layout. CPEC starts from Kashgar and ends at Gwadar Port, which is also the Belt and Road Initiative's flagship project. The China-Pakistan Economic Corridor will become an important energy corridor and trade corridor, which will have a significant impact on Pakistan's economic and social development. The development of the Belt and Road and the China-Pakistan Economic Corridor project have brought unprecedented development opportunities to the port of Gwadar. How to integrate the construction of Gwadar into the CPEC and the $\mathrm{B} \& \mathrm{R}$ grand layout, and make top-level layout planning from a strategic perspective are important issues that urgently need to be resolved in the construction of Gwadar Port.

Aimin Deng, the School of Economics and Trade, Hunan University, Changsha, China

Jiaqi Wang*, the School of Economics and Trade, Hunan University, Changsha, China
Through in-depth research, this paper points out the future development direction of Gwadar Port, and puts forward the strategic goal, strategic path and development strategies of Gwadar Port logistics development, as well as specific measures to ensure the implementation of the strategies. This study provides a scientific decision-making basis for the ports with a weak foundation to achieve great-leap-forward development, and has important practical significance for the strategic formulation and construction layout planning of the port. The general idea of this paper is as follows: The general idea of this paper is as follows: firstly, it sorts out the relevant literature at home and abroad on port development evolution, development driving force and development strategy, systematically analyzes the trend and law of port development, and draws lessons from its successful experience. Then on this basis, it defines the general strategic goal of the development of Gwadar Port logistics, and puts forward three stage goals with the time dimension. At last, combined with the social and economic development, policy orientation and the development trend of port logistics, the paper puts forward six development strategies suitable for the construction of Gwadar Port, and gives the corresponding specific measures.

\section{LITERATURE REVIEW}

As an important transit station for trade at home and abroad, port logistics has an important influence on economic development because of its superior location and unique functions (Zhuang Q W and Wang J 2005). In order to promote the development of port logistics and make it better serve the logistics practice, domestic and foreign scholars' researches on ports mainly focus on the following aspects:

Port development and evolution. The development and evolution of ports can be traced back to the "Arbitrary port" model proposed by Bird (1971), who believed that the evolution of ports would go through three stages: establishment, expansion and specialization. This model summarizes the process of traditional ports from scratch. Notteboom and Rodrigue (2005) proposed a port system development model. This model divides the evolution of the port system into six stages. The first three stages are the pre-containerization stage, the technical test stage and the consolidation and centralization stage. The latter three stages are hub port centralization stage, diffusion and offshore hub stage and regionalization stage. Ye S L et al. (2018) found that the overall spatial pattern of port logistics along the Yangtze River tended to be decentralized from 2004 to 2014. 
Zhang X F et al. (2019) found that the port systems along the "Maritime Silk Road" presented a hierarchical distribution layout in the process of evolution, and the connections among port groups gradually presented a networking trend.

Port development driving force. Cullinane et al. (2005) believe that improvements in port natural endowments, prices, and logistics service quality will allow Ningbo Port to gain a greater market share. Wu Q D et al. (2011) elaborated on how technological progress, shipping market, geographical location and political policies drive the evolution of port system by building a dynamic model of port system. Peng B (2012) conducted relevant studies on port development and comprehensive competitiveness improvement during the period of "10th Five-Year Plan" and "11th Five-Year Plan", and found that the main reasons for port development from weak to strong were port competition, clustering and changes in logistics demand structure. Yang B (2016) analyzed the internal driving force of port evolution in the context of port inter-generational development, and found that the difference in demand for regional development will have a great impact on the port development model. Therefore, it is necessary to give full play to the driving role of different factors when formulating port strategy.

Port development model. Liu G Y and Ruan S P (2009), based on the concept of "port regionalization" proposed by Notteboom (2009), proposed three specific development models: star model, network model and family model, and discussed the development of various models, and discussed the advantages and disadvantages of each mode. Taking Yangshan Port as an example, Wang C J et al. (2016) summarized the port construction control, shipping network, container feeding and economic self-organizing model of offshore hub port. Through systematic research, Zhang M T et al. (2016) summarized the evolution model of Shanghai port, which is "the stage of a single port area in a river- the stage of two-way river extension- the stage of industrial shoreline expansion- the stage of containerized offshore relocation". Xu P et al. (2016) put forward the concept of port logistics hub and three development modes of port, namely transportation center, port-city logistics hub and international logistics hub, and summarized their development characteristics.

Port development strategy. Xue J and Yi X (2005) believed that when port logistics enterprises faced price war, they should choose differentiation strategy and form regional port logistics enterprise alliance. Yao G et al. (2009) determined creative and flexible solutions from a strategic perspective for the development of China's free trade port area to achieve sustainable development. Girard (2010) formulates a new port area development strategy through the evaluation process, and suggests an effective evaluation process in terms of strategy, execution and management planning, so as to realize the tangible and intangible value of the port and urban area. Aiming at the low accessibility of Scottish ports, Monios and Wilmsmeier (2012) put forward specific strategies to improve the physical and institutional double externalities of port center logistics, dry port logistics and offshore logistics centers. Ruan X et al. (2018) conducted relevant studies on the construction of service network of ports along the Belt and Road, which was applicable to the strategy formulation under the new policy environment. Liu T S (2011), Deng J F (2017), Liu B F et al. (2018) and Chen C (2019) respectively conducted relevant studies on the development strategies of many Chinese ports.

\section{GWAdAR Port LOGISTICS StRAtegic OBJECTIVES}

\section{A. General Strategic Goal of Gwadar Port}

According to the development plan of Gwadar Port, by 2030, Gwadar Port will be built into a modern, international, green and intelligent hub port, which meets the modern port characteristics of reasonable structure, smooth flow of information, complete function, distinct layout, safety and efficiency, and realize the transformation from ports, free trade zones and international cities. At the same time, it also undertakes radiation to drive southern Pakistan and Baluchistan, even the important task of development in Central Asia.

\section{B. Strategic Path of Gwadar Port Logistics Development}

According to Gwadar Port's development plan, development environment and world port development laws, the strategic path of logistics development of Gwadar Port roughly follows: the development model of port transport center-port city logistics hub-international logistics hub (Fig. 1). However, the development of the port is not strictly in accordance with this path for step-by-step development, but will reflect the evolution characteristics of this development model in the process. The functions of each stage can cross each other in the development of Gwadar Port. Therefore, in the formulation of strategic objectives, the authorities should consider all stages of the omni-directional top-level design to promote the great-leap-forward development of Gwadar Port.

\section{Strategic Objectives and Strategic Deployment of Gwadar Port in Three Stages}

In order to realize the leapfrog development of Gwadar Port logistics, it is necessary to establish a phased strategic target system.

\section{Forward stage development objective}

By 2020, centering on the port construction, Gwadar Port will take the realization of transportation center as the main goal, while in view of the construction of port park and letting the development of port-industry-city-region integration in the starting state. Firstly, it is necessary to improve the utilization rate of Gwadar Port, increase the port's cargo throughput, and realize all the basic functions of the port. Then, it is necessary to strengthen the construction of the port collection and distribution system, and carry out reasonable planning and layout of logistics parks, industrial parks, free trade zones and other parks. The focus is to form a complete port logistics supply chain system so that each element in the port industry supply chain system can perform its duties, to maximize the benefits of the entire port supply chain. Finally, Gwadar Port should improve the operation level of the port generally to ensure that goods can be transported to the corresponding link quickly, safely and accurately, and to improve the efficiency of supporting port services so that goods can be quickly cleared. At the same time, the Gwadar 
Port should start to pay attention to the links with cities, industries and regions.

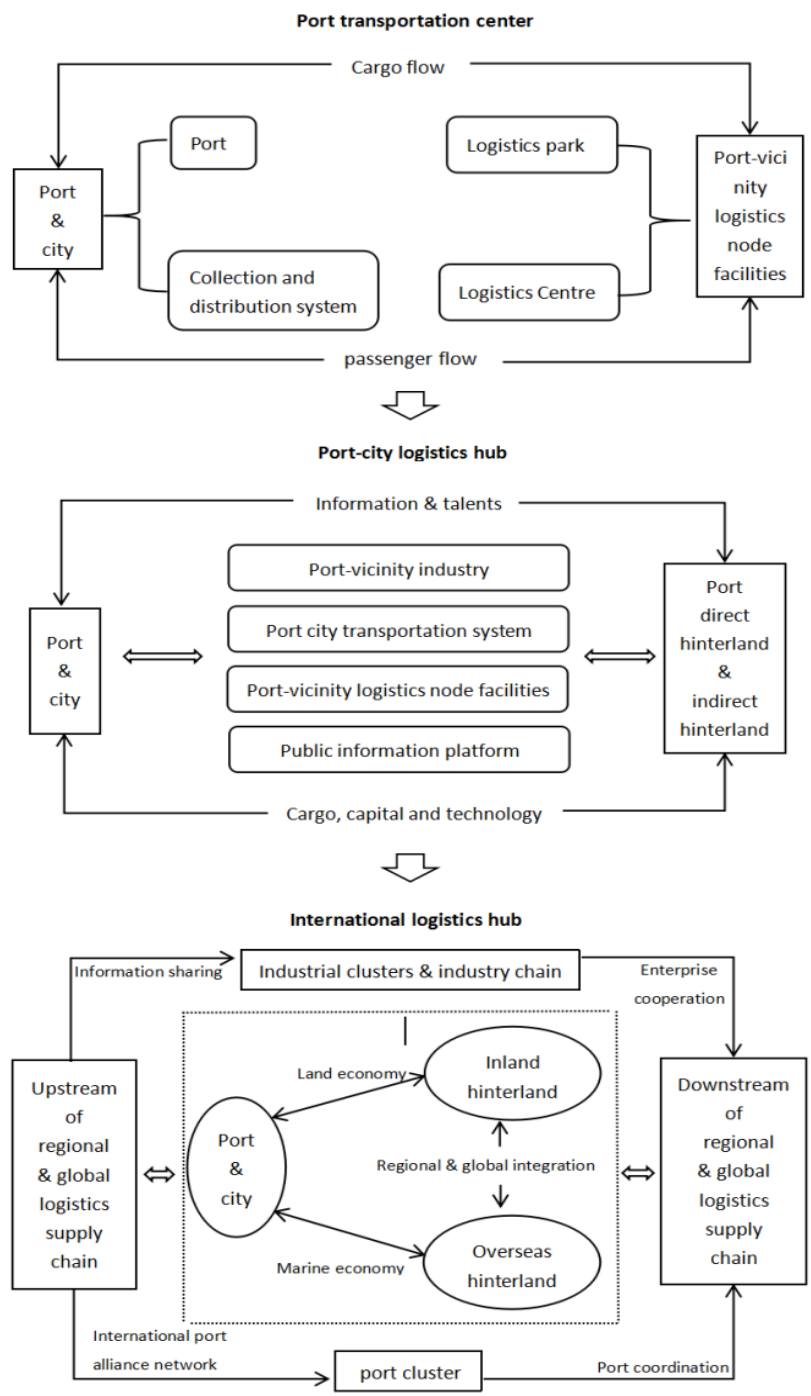

Figure 1 Gwadar Port development path

\section{Intermediate stage development objective}

By 2025, Gwadar Port will achieve the port-city logistics hub as its main development objective, and at the same time vigorously develop the port-vicinity industry to provide a strong motivation for port development, and gradually expand the port's influence to the port-vicinity and near port areas. At this stage, Gwadar Port initially reached the international level in terms of throughput, operation efficiency and route opening, and the port performance showed a trend of rapid growth. The joint construction of port and city is reflected in the following aspects: the establishment of a scientific and modern transportation and logistics system between ports and cities; developing competitive industries centered on minerals, coal and energy to form a complete industrial chain, industries are clustered in the port and land hinterland to form a positive external scale effect; the gathering of industrial parks, export processing zones, logistics parks and other parks provides a platform for the prosperity of the port industry; establishing e-commerce information platform that can be shared by port-vicinity, near port and far port areas. The good interaction between the port cities will spread the influence to Baluchistan and even the whole Pakistan. While the port's hard power is improving, it has gradually begun to develop its soft power, paying attention to the ecological balance of the port area, and moving towards sustainable development.

\section{Long-term stage development objective}

By 2030, with the continuous deepening of the China-Pakistan Economic Corridor and the Belt and Road project, Gwadar Port will become the largest and most powerful international logistics hub port in the western part of Pakistan and become an international logistics hub facing South Asia and adjacent to the Middle East. Internationally, Gwadar Port has gradually mastered the voice and dominance in the port supply chain, expanding its influence to the far port area, becoming a transit point for China-Pakistan energy transportation and having trade, industrial and commercial functions. The city of Gwadar, the direct hinterland of the port of Gwadar, has become the central city in the southwest of Pakistan. It has played role to drive the economic development of the whole region, becoming an important carrier of port-city integration, regional integration and global integration, attracting the spatial convergence of related manufacturing and service industries, and derivative various related industries to form industrial clusters. On this basis, Gwadar Port has expanded and extended its economic hinterland, connected with Central Asia, East Asia and West Asia, increased trade exchanges, and become an international cargo distribution center, making Gwadar Port an important participant in the international division of labor. Meanwhile, the soft power of the port has been significantly improved compared with the previous stage, the image of the port is more international, and sustainable development has become a long-term goal.

\section{GWAdAR Port LOGistics DEVElopment STRATEGIES}

\section{A. Port-industry-city-region Integration Strategy}

Port economy consists of three subsystems (Fig. 2), which are port transportation system, port hinterland system and port industry system. The port, industry and hinterland influence and relate to each other, so the development of the port needs the three subsystems to play a role together, and the relative backwardness of any subsystem will affect the overall development.

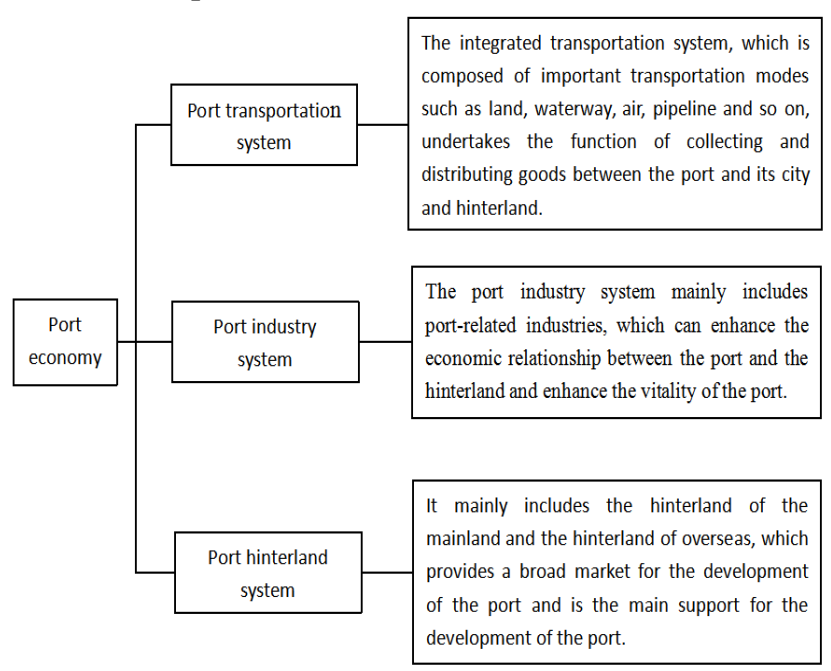

Figure 2 Port economic composition system 
Therefore, in order to invigorate the economy of Gwadar Port as a whole, strategic planners need a systematic vision to make the integrated development of the three subsystems of port, hinterland and industry, so as to promote, influence and drive each other. The core of the development of the integrated mode of port-industry-city-region is that the port becomes the import and export base of industrial raw materials, fuel and spare parts with the help of its superior transportation function, providing resources and looking for the market for the products of the port industrial zone; the development of port industry promotes the transformation of port to multi-functional, information-based and efficient industrial production base; the inland hinterland provides public services and supporting facilities such as financial, insurance and information services for the operation of ports and industrial parks; the overseas hinterland provides a broader market for the development of the port and gradually strengthens the international influence of the port.

There is an interactive economic development relationship among ports, industries and cities as shown in figure 3 , in which the port economy embodies the characteristics of endogenesis and leadership when it acts on the urban economy. When the urban economy reacts to the port economy, it shows the characteristics of adaptability and feedback. Industry shows conductivity and support between city and port.

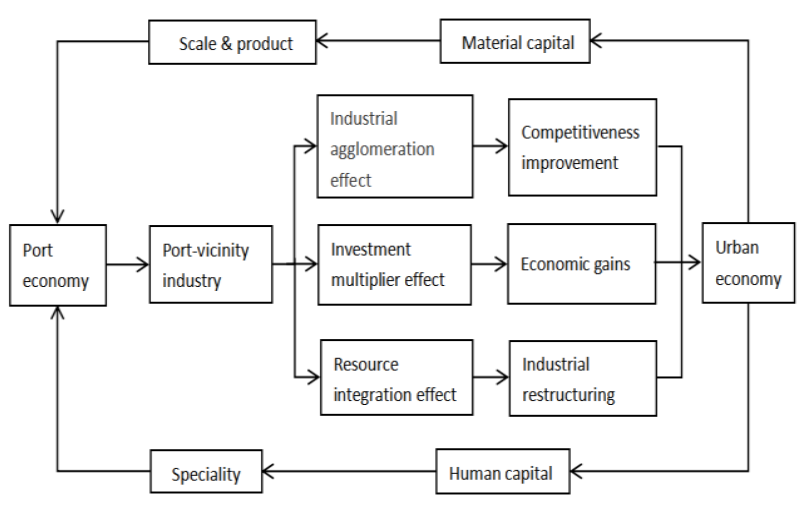

Figure 3 Economic interactions between ports, industries and cities

The strategy of port-industry-city-region integration is a top-level strategy with a global view, which can be divided into four sub-strategies in the concrete implementation, as follows:

\section{Logistics development strategy between Gwadar Port and direct hinterland}

The development strategy between Gwadar Port and direct hinterland is to optimize the allocation of logistics network in Baluchistan province. The main task of the early stage is to give full play to the driving role of the port, including: speeding up the construction of hardware and software of infrastructure, supporting facilities and logistics information platform; forming logistics network system as soon as possible according to the functional orientation of each logistics park and city to meet the import and export service of Gwadar Port logistics; and further strengthening the construction of transportation system between port and city. In the medium term, the focus of construction will be shifted to the city. On the one hand, it is necessary to strengthen the construction of urban infrastructure, on the other hand, to attract talents and create a foundation for the development of urban industry.

\section{Logistics development strategy between Gwadar Port and indirect hinterland}

The indirect hinterland of Gwadar Port mainly refers to the Indus River Basin in Pakistan, through which Gwadar Port can connected with Karachi Port and Kasim Port. Through the capital of Pakistan, the most economically developed eastern part of Pakistan which connected with the Gwadar Port. The strategy for the indirect hinterland is to speed up the process of regional economic integration by establishing regional cooperation institutions and formulating corresponding development plans, in order to achieve resource integration and overall development.

\section{Strategy of expanding the development of overseas hinterland through regional cooperation}

Because of its geographical location, Gwadar has great potential to become an important international port, so it has opportunity to continue to explore its overseas hinterland. The construction of Gwadar Port will open the surrounding landlocked countries, especially the Central Asian countries represented by Afghanistan. Gwadar Port can be linked to the Indian Ocean, and the port's influence radiation ranges west to the Gulf region, south to southern India and Sri Lanka, thus further promoting regional economic cooperation and exchange.

\section{Strategy of developing port-vicinity industry}

Industry is an important power source for port to maintain sustainable development, and industry can provide sufficient supply for port. Therefore, the breakthrough point for the integration of port-industry-city-region is to promote port industry. On the one hand, the port industry can promote the development of the port, on the other hand, it can also promote the growth of the urban economy. The industrial development model of Gwadar Port should be determined according to the development environment of port and hinterland. It is necessary not only to develop key industries, but also to play the role of different types of port industries, adjust the industrial structure, and promote the coordinated development of port-industry-city.

\section{B. Alliance Strategy}

The competition in today's world is no longer between individuals, nor are ports. The competition between port and port gradually evolves into the competition between port group and port group, port alliance and port alliance, and the fourth generation port has shown obvious network characteristics. Alliance strategies can integrate upstream and downstream resources to reduce costs and improve efficiency. The alliance strategy can be divided into two types, one is the horizontal alliance between the port and the port, and the other is the vertical alliance between the port and the members of the upstream and downstream port supply chain.

\section{Horizontal alliance strategy}

The horizontal alliance between ports is represented by 
some kinds of agreement between ports and ports or between port groups and port groups. Within the alliance, resources are reasonably arranged and shared, and the functions of ports are positioned differently to avoid repeated waste of resources and vicious competition. The flow speed of logistics, capital flow and information flow within the port alliance will be greatly improved compared with the non-alliance state, to reduce the port operation cost and risk. Horizontal alliance can also be divided into intra-regional port alliance and inter-regional port alliance according to the scope of port hinterland.

For the intra-regional port alliance, Gwadar Port can implement the alliance strategy with the two major ports of Karachi Port and Qasim Port in Pakistan, and make use of the policy to carry out unified scheduling of resources, to facilitate the misplaced development of ports and achieve win-win results. For the inter-regional port alliance, the most favorable alliance object that Gwadar Port can choose is the port along the "Maritime Silk Road ", which can help Gwadar Port to enter the global logistics transportation network quickly. Enhance the visibility and image of the port.

\section{Vertical alliance strategy}

Port vertical alliance is mainly implemented from the perspective of the upstream and downstream members of the port supply chain, including port-cargo alliance, port-shipping alliance and port-park alliance.

The port-cargo alliance refers to the cooperation between the port and the cargo owner. The port-cargo alliance can enable the demand side, that are, the cargo owners, to focus on their core business, which is in line with today's supply chain management ideas; the supply side, that is, the port, can continuously improve the professionalism of the business, develop to the flexible port supply chain according to the needs of different customers, and continuously extend the port industry chain. Port and shipping alliance refers to the formation of cooperative relations between port and port transporters, especially with shipping companies. At present, a variety of cooperation methods have been formed in this market, such as the joint operation of port and liner companies through equity participation, which can make the assets use together among the partners, reduce the capital pressure, improve the transaction efficiency, and share profits and risks between the two sides. Port-park alliance refers to the union between port and industrial park, logistics park, free trade area and so on. The representative development mode is the integrated development of port-bonded area. Preferential policies coupled with the improvement of customs convenience greatly promote port trade, enhance the level of economic development of the port, and promote the development of related industries, such as logistics industry, processing manufacturing industry and so on.

\section{Differentiation Strategy}

Differentiation strategy is a kind of strategy that enterprises use most in the face of monopoly competition market. It can carry out product marketing design according to the needs of customers in a certain aspect, and provide customers with unique value. Then make the enterprise obtain the product premium. For the port logistics industry, emphasis should be placed on product differentiation, process differentiation, service differentiation and image differentiation, in which service differentiation can increase the added value of products.

Port service differentiation is to take the service provided by customers as the object, differentiate the service in order to gain competitive advantage. The first is to provide the corresponding exclusive service according to the customer's demand, and to provide different supply chain modes to different customers, which requires the operating system of the port logistics base or center to be flexible; The second is to integrate business flow, logistics, information flow, capital flow, speed up the flow of all kinds of resources, improve the response capacity of the whole logistics system; thirdly, it is necessary to reduce the uncertainty of port logistics system, especially the time problem and security problem, and avoid the unnecessary inventory risk and cost caused by the port operation system.

\section{Opening-up Strategy}

Port is the gateway of a country, the opening degree of port is closely related to the degree of foreign trade development of this country, the more developed the foreign trade, the more specialized and advanced the port. As the "leader" of the port economy, the port should increase the intensity of opening up and constantly lead the hinterland cities to the direction of opening up to the outside world and developing export-oriented economy. This requires policy support from the state, especially with regarding to tariffs, and the establishment of relevant free zones will help attract foreign investors and enterprises to set up factories or trade near the port of Gwadar. Gwadar Port can learn from the idea of "attracting investment by resources and promoting development by investment", actively cooperate and exchange with foreign countries, learn the concept, management mode and operation mode of advanced ports, and improve the international level of the port.

\section{E. Talent Strategy}

While improving the hard power of the port, it is also necessary to strengthen the soft power construction of the port. The introduction and training of port professionals is a necessary way to enhance the soft power. Therefore, Gwadar Port needs a lots of logistics or port construction talents with relevant professional knowledge, which requires the implementation of talent strategy. In terms of talent introduction, the key is to form an institutional environment to attract talents, to establish a local talent incentive mechanism, and to speed up the formation of a market-oriented allocation mechanism of human resources to achieve the purpose of attracting, training and retaining senior talents. In terms of human resources training, in the short term, the effective way is to carry out professional vocational and technical education on the existing local human resources, and in the long run, improving the educational environment is the fundamental solution.

\section{F. Strategy of Sustainable Development}

The development of port logistics should pay attention to ecological benefit while realizing economic benefit. The green development of port has very important strategic and 
practical significance to realize sustainable development. The main purpose of implementing the port sustainable development strategy is to realize the harmony and unity among people, ports and the environment, and can not promote the development of the port at the expense of the environment. It is necessary to carry out reasonable planning for the sustainable development of ports, strengthen the construction of environmental management systems, continuously introduce and implement energy saving and emission reduction technologies and advocate green transportation.

\section{V.MEASURES FOR THE IMPLEMENTATION OF THE}

\section{STRATEGIES}

\section{A. Measures for Forward Stage Development Objective}

The measures in the early stage mainly revolve around the realization of the port transportation center. Through the advanced technical transformation and upgrading of the port infrastructure, port equipment modernization level, to ensure the full realization of port functions, so that Gwadar Port becomes a modern port, while taking into account the port city production areas linked to the infrastructure.

\section{Improve port infrastructure and enhance port transport capacity}

The improvement of port infrastructure construction and port operation equipment is the basic guarantee for the development of Gwadar Port into an international hub port. Gwadar Port should continue to purchase international advanced machinery and equipment, introduce advanced technology, build professional logistics terminals with operational standards, and comprehensively improve the adaptability of Gwadar Port to the needs of international logistics.

Gwadar Port should build a modern port multimodal transport system, give full play to the basic supporting role of transportation, and form an efficient and smooth traffic network. First, it should strengthen railway construction, gradually upgrade existing tracks, build new sections of roads, increase the mileage of double lines, and build railways connecting the Gwadar region. Second, it is necessary to rationally plan the construction of highway line stations, form a smooth highway line network, upgrade the highway grade, and arrange the roads in the port into a circular line so that transport vehicles can pass through, and minimize crossing with railway lines or interfering with loading and unloading production operations. Third, as soon as possible to implement the construction of Gwadar Airport and pipeline laying, improve the layout of traffic networks. Gwadar Port should promote multimodal transport, form an efficient inter-modal connection system, and enhance the capacity of port collection and distribution.

\section{Strengthen port soft power and improve the level of port informatization}

Gwadar Port should take Internet technology as the fulcrum, standardize operation as the principle, and strengthen the construction of port soft power. Through the use of $5 \mathrm{G}$ communications, cloud computing, Internet of things, big data and other technologies to promote the port intelligence, digitization, information and systematic level, improve the operational efficiency and service capacity of Gwadar Port, and reduce operating costs. Improving the service function and level of Gwadar e-port, promoting the construction of public information platform and e-commerce platform, such as GPS, GIS, EDI, radio frequency technology, ensuring the high-frequency exchange of a large number of logistics data, and basically forming the big data system of Gwadar port. Integrating enterprise information, import and export customs clearance information, shipping information and warehousing information into an information sharing platform to complete the one-stop experience of information exchange and realize data sharing.

\section{Rational layout of industrial parks and development of key industries}

According to the plan of Gwadar Port, the industry of the Eastern Bay Industrial Park is mainly composed of three major plates: one is heavy industry, which is dominated by mineral processing, energy and chemical industry, and iron and steel manufacturing; the other is to form a processing industry in Gwadar Port, including textile and clothing processing, food manufacturing, agricultural and seafood processing; and the third is to develop oil, natural gas and refining industries taking into account the resource endowment of Gwadar Port. These three sections have been a set of more mature and perfect industrial system, and the three complement each other and develop together, forming the industrial foundation of Gwadar Port development. Industrial parks with reasonable layout around key industries depend on the interrelation between parks to form scale effect.

\section{Develop talent introduction plan to provide quality human capital}

Firstly, according to the needs of Gwadar Port construction, related institutions should formulate an effective human resource plan to solve the current situation of lack of port logistics personnel in Gwadar Port. On the one hand, cooperating with colleges and universities to train professionals and establishing a long-term talent transportation and training base, especially the cooperation of Chinese universities. With the help of the scientific research strength of higher education, it provides a strong talent guarantee for the sustainable development of port logistics. On the other hand, it is necessary to educate and train the existing labor force modern logistics basic knowledge and professional knowledge, popularize vocational education, and establish schools related to port logistics skills.

\section{B. Measures for Intermediate Stage Development Objective}

In the medium term, the logistics construction of Gwadar Port mainly revolves around the interaction between port economy and urban economy, which promotes the capital flow, technology flow, intelligence flow and information flow to the port city logistics hub, and drives the port industry to flourish. At the same time, the scope of influence of the port gradually deepens to the near port area. 


\section{Determine the development model of port-adjacent industry and build a characteristic industrial system}

Based on the experience of port industry development at home and abroad, combined with the actual situation of Gwadar Port and the background of China-Pakistan economic corridor and the Belt and Road, Gwadar Port industry should adopt a comprehensive production development model (Yu S H, 2007). The government issued policies to guide the combination of industrialization and urbanization, to form a port industry development model based on heavy industry, and to actively undertake industrial transfer in developed countries and strengthen the level of domestic industrialization.

Building a port, port-vicinity and near-port coordinated industrial system. Gwadar can form a complete industrial chain and an export-oriented economy in agriculture, fruits and vegetables and fishery, increasing port exports; at the same time, Gwadar can develop relatively environmentally friendly and high value-added port services. Balochistan relies on abundant resources to become Pakistan's domestic raw material base, with convenient shipping conditions to develop mineral and natural gas-based pillar industries, providing a stable upstream supply for the development of related industries, forming a complete mining-production-processing-transport-sales system in the province (Fig. 4). It can also be combined with the existing industrial zones of Baluchistan to develop coal industry, petrochemical industry, metallurgical industry and so on, to form a cluster of heavy chemical industry with agglomeration influence.

For Pakistan, firstly, it is necessary to develop the secondary industry with the help of the port-vicinity heavy industry system, optimize the industrial structure, and solve the unbalanced development in the east and west. The first is to unite the industrial areas. Karchi, Mirpurkhas, Qasim, Tandu Adom, Sukkur, Quetta and other industrial zones in Pakistan are all industrial zones, of which there are coalfields near Qasim and Mirpurkhas and oil fields near Sukkur. The supporting industrial industries are mature and can be developed jointly with Quetta and Gwadar to form a complete industrial chain. The second is to transfer all industrial zones in the eastern Sindh province to the western Quetta and Gwadar, to stimulate the economic development of the western region, to make up for the lack of industrial gaps in Baluchistan province, and to solve employment and economic problems at the same time, so as to enhance the overall industrial strength of Pakistan.

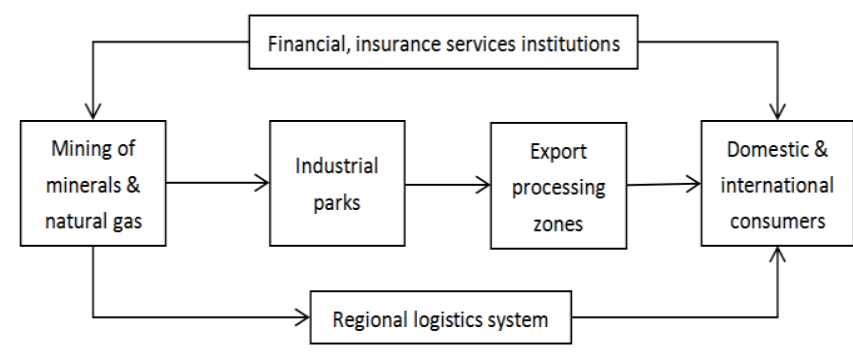

Figure 4 Framework of industrial development in Baluchistan

2. Create a hierarchical regional logistics system and enhance regional linkages
Firstly, it is necessary to pay attention to the coordination between port and urban transportation. The port involves the handling of a lots of goods every day, so the relevant institutions should pay special attention to the reasonable arrangement of port collection and distribution routes to avoid pressure and chaos on urban traffic. Therefore, the transportation development of the port city must comprehensively consider the transport system, including multimodal transport, enhance the supporting facilities of software and hardware, form a scientific, efficient and reasonable traffic network layout, and promote the benign interaction between the port and the city.

Next, it is indispensable to improve the logistics system of Baluchistan with Gwadar Port as the center. Forming a regional collection and distribution network with Gwadar Port as the center and improve the main cities and main industrial parks in Baluchistan. Using "Taftan - Gwadar Turbat - Panjgur - Nag - Basima - Sorab - Qalat - Sibi - Quetta - Chaman" as a communication network, the interconnection between cities in Baluchistan is realized. This line is also part of the Belt and Road Initiative's planned route, which extends the planned line to Gwadar and Quetta, and promotes the development of Gwadar through the influence of the Belt and Road Initiative. The realization of the logistics system will help to promote the economic development of the whole Baluchistan province.

The last part is to build a national logistics system with Gwadar Port as the center. Gwadar Port is the opening door to the outside world in southwest Pakistan. Strengthening the port status and function of Gwadar is very important for it to become an important hub of the national integrated transport system. On the one hand, the authorities should strengthen the strategic cooperation between Gwadar Port and the land area, actively expand the transport network, improve the layout of the transport network, and make use of the opening policy of the free zone of Gwadar Port to promote the extension of port function, port function and bonded function inland. On the other hand, the authorities should vigorously promote sea-rail intermodal transport, optimize railway collection and distribution organizations, strive to increase the proportion of railway collection and distribution, and enhance the closeness and convenience of land and sea links.

\section{Promote port strategic alliance to achieve supply chain penetration}

The authorities should guide Pakistan's domestic ports to unite to achieve misplaced development. The combination of domestic ports can make a reasonable division of labor between ports. Each port can give full play to its own comparative advantages and complement each other at the same time. In the early stage, Gwadar port can set up a joint agreement with Karachi port and Qasim Port, especially Karachi port. Karachi Port is currently the main energy transport port in Pakistan, and Gwadar Port has an important energy strategic position and rich mineral resources. The two ports can connect with the main mineral resources and realize cooperation in energy transportation. Gwadar Port can solve the current development dilemma of Karachi Port by building large berths, undertake part of its business, and reduce the logistics pressure of Karachi Port, while Karachi Port can also transfer part of its logistics business to Gwadar Port to drive the development of Gwadar Port. 


\section{Measures for Long-term Stage Development Objective}

At this time, the port logistics hub service mainly takes the far port area where Gwadar is located as the core and carrier, which is manifested in the following aspects: the port logistics service connects with the international logistics system; the port and urban industries move closer to the service industry; the port hinterland extends to the far port range; the process of regional integration and global integration is accelerated.

\section{Develop the port service industry and promote the optimization of industrial structure}

Port-related industry is an important driving force for the high quality of urban hinterland economy, which helps the city to transform to logistics center, information center and financial center, and strengthens the regional radiation capacity. On the basis of the development of port and heavy industry, Gwadar should vigorously develop logistics consulting industry, logistics financial service industry, shipping information business, shipping supervision business and other related tertiary industries, and optimize the industrial structure, so that the industrial structure can develop to the trend of softening. In addition, it is necessary to vigorously develop the modern logistics industry and information service industry, establish an information platform, and introduce a logistics technology standardization system and advanced information management system in line with international standards. The state should also encourage Gwadar Port to develop third-party and fourth-party logistics industry and develop modern logistics industry operation mode basis on the original port logistics business.

\section{Enhance the quality of bilateral trade between China and Pakistan and steadily advance the construction of China-Pakistan Economic Corridor}

In the trade exchanges between China and Pakistan, China has always been in the position of trade surplus. In order to narrow the trade balance between China and Pakistan and promote the balanced development of trade between China and Pakistan, China should increase its imports of Pakistani goods, narrow the trade balance between the two countries, and alleviate the imbalance in Pakistan's trade balance. China and Pakistan are complementary in commodity trade, so the trade of complementary commodities should be expanded. China should increase imports of agricultural products, cotton textiles and other commodities from Pakistan. Pakistan should increase its imports of high-tech machinery and equipment from China. This will enhance the complementarity of bilateral trade, thus promoting the expansion of trade scale and reducing trade competitiveness.

\section{Promote the integration of ports along the "Maritime Silk Road" and enhance the international influence of ports}

According to the hub location optimization method, using the trade flow and shipping distance data of the ports along the "Maritime Silk Road", and comprehensively considering various factors such as trade flow between countries, cargo structure, regional enterprise relations and safe geo-environment, select the hub route with the lowest transportation cost, and draw the conclusion that the optimal location choice of the hub port in South Asia is the Gwadar
Port (Yuan L L, 2017). This hub route is " ShenzhenGuangzhou (China)- Singapore (Southeast Asia)- Gwadar (South Asia)- Port Jeddah (West Asia and North Africa)- Port Sed (Mediterranean coast)". Therefore, Gwadar port should strengthen the connection with the port on the Maritime Silk Road hub route, realize the cooperation in the supply chain, and promote the formation of the port alliance with upstream and downstream business relations. In terms of regional links, the port of Gwadar can strengthen its ties with the five Central Asian countries and Afghanistan, become its main sea outlet, and seek cooperation with the port of Chabahar in the competition. Finally, Gwadar Port should make full use of financial organizations such as the AIIB and the Silk Road Fund to solve the funds needed for regional infrastructure construction along the route to ensure the smooth implementation of the Gwadar hub port optimization project.

\section{CONCLUSION}

Gwadar Port is located near the Persian Gulf of strategic significance, clutching the throat of several important maritime routes, is the end point of the China-Pakistan Economic Corridor, and is also an important hub port along "the Belt and Road ". Therefore, in the strategic planning of Gwadar Port, it is necessary to formulate a comprehensive, hierarchical, targeted and leapfrog strategic plan according to the unique characteristics and needs of Gwadar Port. Firstly, this paper puts forward the strategic general goal of the development of Gwadar Port logistics and the sub-objectives of three stages within 10 years. Secondly, considering the policy advantages, industrial potential, geographical location and other factors, this paper puts forward six major development strategies: the port-industry-city-region integration strategy, alliance strategy, the differentiation strategy, the sustainable development strategy, the opening-up strategy and the talent strategy. Finally, the corresponding implementation measures are put forward around the goal and development strategy. This paper has strong practical and practical significance for exploring similar weak foundation but unique advantage port to realize leapfrog development.

\section{ACKNOWLEDGMENT}

This research was financially supported by the project of National Social Science Fund of China: "Research on Logistics Development in Gwadar Port Based on the Belt and Road" and the Sino Pakistani Economic Corridor (No. 18BJY168).

\section{REFERENCES}

[1] Zhuang Jingwei, Wang Jian. Development and enlightenment of foreign port logistics. Logistics Technology. 2005.

[2] Bird J H. Seaports and Seaport Terminals. London: Hutchinson,1971. pp. 1-26

[3] Notteboom T, Rodrigue J P. Port regionalization: Towards a new phase in port development. Maritime Policy \&Management, vol 3, 2005, pp. 297-313.

[4] Ye Shilin, Cao Youhui, Wang Jiawei, et al. Spatio-temporal evolution characteristics and mechanism of the port logistics system along the Yangtze River. Geographical Research, vol 5, 2018, pp. 925-936.

[5] Zhang Xinfang, LYv Jing. Spatial-temporal pattern and evolution of port system along the 21 st-Century Maritime Silk Road. Economic Geography, vol 11, 2019, pp. 33-40. 
[6] Cullinane K, Teng Y H, Wang T F. Port competition between Shanghai and Ningbo. Maritime Policy\& Management, vol 4, 2005, pp. 331-346.

[7] Wu Qidao, Zhang Hongou, Ye Yuyao, et al. Factors and driving mechanism of the port system evolution. Human Geography, vol 3, 2011, pp. 106-110.

[8] Peng Bo. The dynamic correlation effect analysis of Zhejiang coast port development and comprehensive competitiveness promotion. Economic Geography, vol 5, 2012, pp. 87-92.

[9] Yang Bin. Analysis on port development model driven by regional economy. Port Economy, vol 5, 2016, pp. 5-8.

[10] Liu Guiyun, Ruan Shiping. Mode of port regionalization development. Journal of Ningbo University (Natural Science \& Engineering Edition), vol 1, 2009, pp. 148-151.

[11] Notteboom, T. The terminalization of supply chains: reassessing the role of terminals in port hinterland logistical relationships. Maritime Policy \& Management, vol 2, 2009, pp. 165-183.

[12] Wang Cheng, Zhang Mengtian, Cheng Jiajia. Spatial pattern of offshore hub port and development mechanism — the case of Yangshan Port in Mainland China . Economic Geography, vol 6, 2016, pp. 100-108.

[13] Zhang Mengtian, Wang Chengjin, Wang Chenglong. Regional evolution, function evolvement and driving mechanism in the development of Shanghai port. Geographical Research, vol 9, 2016, pp. 1767-1782.

[14] Xu Ping, Liu Xiaolei, Gao Aiying, et al. Analysis on internal development mechanism of port logistics hu. Port Science \& Technology, vol 3, 2016, pp. 6-12.

[15] Xue-Jun F, Yi-Xin Y. Strategy choice of port logistics enterprises in price war. Journal of Traffic and Transportation Engineering, 2005.

[16] Yao-Guang Z, Kai L, Gui-Chun L, et al. Research on development strategy and distribution characteristics of Chinese free trade port zones. Economic Geography, 2009.

[17] Girard L F.Creativity, Resilience: Toward New Development Strategies of Port Areas through Evaluation Processes. International Journal of Sustainable Development, vol 13, 2010, pp. 161-184.

[18] Monios J, Wilmsmeier G. Port-centric logistics, dry ports and offshore logistics hubs: strategies to overcome double peripherality. Maritime Policy \& Management, vol 39, 2012, pp. 207-226.

[19] Ruan X, Feng X, Pang K. Development of port service network in OBOR via capacity sharing: an idea from Zhejiang province in China. Maritime Policy \& Management, vol 45, 2018, pp. 1-20.

[20] Liu Tianshou. The analysis of development strategy for Guangxi Beibu Gulf Port logistics. Southwest Jiaotong University, 2011.

[21] Deng Jianfeng.Study on the potential evaluation and development strategy of Ningbo-Zhoushan Port. Zhejiang Ocean University, 2017.

[22] Liu Bangfan, Guo Yifei, Li Junjie. Implementation of the development strategy of integration of coastal port, industry and city to help Hebei Province open development. Economic Research Guide, vol 29, 2018, pp. 35-36.

[23] Chen Cong. Study on the development strategy of green port construction in Qingdao Por. Yanshan University, 2019.

[24] Yu Shuhui. Research on development models of port-neighboring industry: a case study of Fujian Province. Fujian Normal University, 2007.

[25] Yuan Lili, Ji Peng. Optimization of Regional Hub Ports along the "21st-Century Maritime Silk Road". Economic Geography, vol 37, 2017, pp. 1-9.

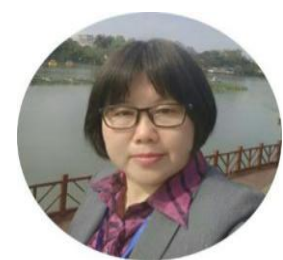

Deng Aimin, Ph.D., Professor of School of Economics and Trade, Hunan University, $\mathrm{Ph}$.D. Supervisor, Director of the Institute of Transportation and Logistics, Hunan University; the first batch of scholars of the Hundred Talents Project of Hunan Province, Director of the Expert Committee/Vice President of Hunan Modern Logistics Society, Expert in the evaluation of master's and doctoral dissertations in the degree center of the Ministry of Education, and Expert in reviewing the National Social Science Fund.

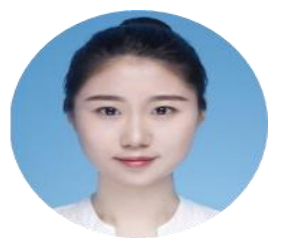

Wang Jiaqi, Master's degree from Hunan University; Major in Internation Trade. The research is supply chain management and logistics. 